\title{
Overview: Underserved Areas of Education in the Responsible Conduct of Research: Authorship
}

\author{
Michael W. Kalichman
}

Received: 23 March 2011/Accepted: 16 April 2011/Published online: 26 May 2011

(C) Springer Science+Business Media B.V. 2011

\begin{abstract}
In February of 2007, the Responsible Conduct of Research Education Committee of the Association for Practical and Professional Ethics convened a mini-conference at the Association's annual meeting. The purpose of the miniconference was to examine underserved areas of education in research ethics. The mini-conference consisted of panel discussions for two topics: authorship and social responsibility. Representatives from diverse academic disciplines were invited to participate in each of the two panels. This Special Section of Science and Engineering Ethics consists of the papers based on presentations in the authorship panel. The papers illustrate similarities and differences in authorship and publication practices in various disciplines including engineering, the life sciences, and the social sciences.
\end{abstract}

Keywords Responsible conduct of research · RCR · Research ethics · Authorship · Education · Teaching

The phrase "responsible conduct of research" (RCR) is well known in the biomedical research community largely because of a long-standing requirement that training grants funded by the National Institutes of Health (NIH) should include a component of training in the responsible conduct of research (National Institutes of Health, and Alcohol, Drug Abuse, and Mental Health Administration 1989). When first announced as a requirement for funding of training grant applications, the scope of the requirement was limited to only a few topics (National Institutes of Health 1992):

M. W. Kalichman $(\bowtie)$

Research Ethics Program, University of California, 9500 Gilman Drive, San Diego,

La Jolla, CA 92093-0612, USA

e-mail: kalichman@ucsd.edu 
Conflict of interest, responsible authorship, policies for handling misconduct, policies regarding the use of human and animal subjects, and data management.

The implication was that it was important for researchers to understand the "responsible conduct of research." In subsequent years, several different books relevant to research ethics were published, including: Francis Macrina (1995), Ruth Bulger et al. (1993), and Deni Elliott and Judy Stern (1997). All of these books raised research ethics questions beyond the scope laid out in the NIH requirement. Based on these texts, as well as a growing number of courses designed to meet the RCR requirement, the Office of Research Integrity proposed a list of topics that would be required for all researchers funded by the Public Health Service (Department of Health and Human Services 2000). While this list of topics (Table 1) emphasized a broader meaning of "RCR," it also continued to foster the notion that scientific integrity, or the ethics of research, is limited to certain defined topic areas. Although the requirement was suspended soon after it was announced (Office of Research Integrity 2001), many instructors and courses still use this list as a basis for what should be covered. As noted in Table 1, a much wider variety of topics might appropriately be considered as part of a research ethics curriculum.

Coincidentally, the same month that the PHS requirement was suspended (Office of Research Integrity 2001), an RCR education summit was convened to address the challenges perceived by federal agencies and others in the non-governmental research community. The purpose of the summit was to assess how integrity in science might best be fostered given an apparently insurmountable challenge: the research community has been reluctant to allocate scarce funds to research ethics education programs unless required to do so, but it has been difficult to create federal requirements that are not overly prescriptive and inappropriately "one size fits all." Discussions at that summit were the impetus for the creation of a national, non-governmental organization, which would both promote RCR education and foster a collaborative environment in which effort and resources could be shared. This national partnership, initially titled the RCR Education Consortium in 2002,

Table 1 List of topics proposed by the Department of Health and Human Services (2000) and examples of other relevant topics for courses in "responsible conduct of research" or "research ethics"

\begin{tabular}{ll}
\hline Department of health and human services & Examples of other relevant topics \\
\hline $\begin{array}{l}\text { Data acquisition, management, sharing, and ownership } \\
\text { Mentor/trainee relationships }\end{array}$ & Social responsibility \\
Publication practices and responsible authorship & Stem cells \\
Peer review & Biosecurity \\
Collaborative science & Dual use technology \\
Human subjects & Environmental health and safety \\
Research misconduct & Computers and information technology \\
Conflict of Interest and commitment & Fiscal responsibility \\
& Conflict resolution \\
\hline
\end{tabular}


has evolved to become the RCR Education Committee, a special interest group of the Association for Practical and Professional Ethics (Kalichman 2007).

As the RCREC prepared for the 2007 annual meeting of the APPE organization, it was clear that RCR education remains woefully underserved. This is despite the $\mathrm{NIH}$ training grant requirement, various national research ethics scandals, the creation and subsequent suspension of the PHS requirement for RCR education, and the founding of the RCREC. Unfortunately, the scope of "underserved" has multiple dimensions. Now, 4 years later, significant gaps remain and have become even clearer in the wake of new RCR education requirements from the National Science Foundation (2010).

\section{Underserved Topic Areas}

Interviews and surveys of RCR instructors emphasize a significant reliance on the "ORI topics" rather than a broader sense of what it means to be a responsible researcher (Kalichman and Plemmons 2007; Plemmons and Kalichman 2007). The frequent absence of "social responsibility" as part of RCR courses is just one example of how research ethics training is constrained. In recent years, other areas of possible importance, particularly in some research disciplines, might include ethical implications in stem cell research, biosecurity, dual use technology, and computing (Table 1).

\section{Underserved Disciplines}

It is also noteworthy that federal RCR education requirements have primarily been limited to the NIH training grant requirement (National Institutes of Health, and Alcohol, Drug Abuse, and Mental Health Administration 1989; National Institutes of Health 1992) and an NSF Integrative Graduate, Education and Research Traineeship (IGERT) Award requirement (National Science Foundation 1997). Even with an increased focus on ethics in engineering (Accreditation Board for Engineering and Technology 2000) and sometimes in individual graduate programs, it is far more likely that someone in the biomedical sciences will be familiar with the concept of "RCR" than someone in psychology, engineering, computing, or anthropology. This is now changing with the new NSF requirement (National Science Foundation 2010).

\section{Underserved Researchers}

The nature of existing federal requirements is that RCR education will be required for all trainees funded by the award, but not for all other postdocs and grad students in the same research program, nor for any faculty or staff researchers (Kalichman and Plemmons 2007). The unintended message of this system is not that research ethics education is a part of research, but that it is merely an optional part of 
research training that just happens to be required to receive financial support. Presuming that ethics in research is relevant to all researchers, it is reasonable to wonder why it is expected only for NIH or NSF trainees rather than having the expectation that all researchers should participate in research ethics education, training, and/or discussions. Unfortunately, the current circumstances may do as much to breed cynicism about "research ethics" or RCR as to actually foster an environment in which ethics and responsible conduct are highly valued.

\section{Authorship}

There are many issues that are subsumed under the heading of "RCR," but perhaps no issue is more ubiquitous and contentious than the question of authorship. Regardless of scholarly focus, it is ultimately important for many reasons to receive credit for ones contributions, and this credit is most frequently conferred by being included as an author of a published work. Because of the importance of this form of credit to career advancement, research funding, and credibility to peers, authorship disputes are common in much of science and engineering. This is not just a question of what contribution is sufficient to warrant authorship. Even where the list of authors is agreed upon, disputes can become bitter and long-standing over the correct order in which to list the authors. To some extent, these issues are addressed by policies and guidelines from various stakeholder groups and organizations, but it is not always clear or appropriate that the criteria for authorship should be the same across different disciplines-or even within the same discipline.

\section{RCR Mini-conference}

With a view to finding ways to better address some underserved areas, the RCREC convened a mini-conference for the February 2007 annual meeting of the Association for Practical and Professional Ethics. The topic for one of two panels was authorship. Participants were representative of four very different academic disciplines: Francis Macrina is a microbiologist, Muriel Bebeau is a psychologist, Jason Borenstein is a philosopher working closely with engineers, and Dena Plemmons is an anthropologist. The papers based on the presentations by these individuals make up this Special Section of Science and Engineering Ethics and present the differing views of authorship from these diverse disciplines, as well as authorship guidelines and practices that exist within different disciplines (Bebeau and Monson 2011; Borenstein 2011; Macrina 2011; Plemmons 2011). In addition, in various ways these papers challenge researchers, students and trainees in science and engineering to think more carefully about what it means to be an author (Plemmons 2011). It is hoped that this multidisciplinary collection of papers will serve as an opportunity to more clearly identify the basis for existing disciplinary approaches to authorship, and also frame a discussion about how to design and articulate best practices for authorship across disciplines. 


\section{References}

Accreditation Board for Engineering and Technology. (2000). Engineering criteria 2000. Third Edition. [available at: http://www.ele.uri.edu/faculty/daly/criteria.2000.html, accessed May 2, 2012].

Bebeau, M. J., \& Monson, V. (2011). Authorship and publication practices in the social sciences: historical reflections on current practices. Science and Engineering Ethics 17 this issue.

Borenstein, J. (2011). Responsible authorship in engineering fields: an overview of current ethical challenges. Science and Engineering Ethics 17 This issue.

Bulger, R. E., Heitman, E., \& Reiser, S. J. (1993). The ethical dimensions of the biological sciences. NY: Cambridge University Press.

Department of Health and Human Services. (2000). Announcement of final PHS policy on instruction in the responsible conduct of research, $(R C R)$. Office of Research Integrity, Department of Health and Human Services. [available at: http://grants.nih.gov/grants/guide/notice-files/NOT-OD-01-007.html. Accessed May 2 2011].

Elliott, D., \& Stern, J. E. (Eds.). (1997). Research ethics: A reader. Hanover, NH: University Press of New England.

Kalichman, M. W. (2007). Responding to challenges in educating for the responsible conduct of research. Academic Medicine, 82(9), 870-875.

Kalichman, M. W., \& Plemmons, D. K. (2007). Reported goals for responsible conduct of research courses. Academic Medicine, 82(9), 846-852.

Macrina, F. L. (1995). Scientific integrity. Washington, DC: American Society for Microbiology Press.

Macrina, F. L. (2011). Teaching authorship and publication practices in the biomedical and life sciences. Science and Engineering Ethics 17 This issue.

National Institutes of Health. (1992). Reminder and update: Requirement for instruction in the responsible conduct of research in national research service award institutional training grants. NIH Guide for Grants and Contracts, 21, 2-3. [Available at: http://grants.nih.gov/grants/guide/notice-files/not92236.html. Accessed May 2 2011].

National Institutes of Health, and Alcohol, Drug Abuse, and Mental Health Administration. (1989). Requirement for programs on the responsible conduct of research in national research service award institutional training programs. NIH Guide for Grants and Contracts, $18,1$.

National Science Foundation. (1997). Integrative graduate education and research training program. Program announcement NSF 97-112. [Available at: http://www.nsf.gov/pubs/1997/nsf97112/nsf 97112.htm. Accessed May 2 2011].

National Science Foundation. (2010). B. responsible conduct of research in grantee standards. [Available at: http://www.nsf.gov/pubs/policydocs/pappguide/nsf10_1/aag_4.jsp\#IVB. Accessed May 22011$].$

Office of Research Integrity. (2001). Notice of suspension of 'PHS policy on instruction in the responsible conduct of research'. Federal Register, 66(35), 11032-11033. [Available at: http://ori.hhs.gov/educa tion/congressional_concerns_published.shtml. Accessed May 2 2011].

Plemmons, D. K. (2011). A broader discussion of authorship. Science and Engineering Ethics 17 This issue.

Plemmons, D. K., \& Kalichman, M. W. (2007). Reported goals for knowledge to be learned in responsible conduct of research courses. Journal of Empirical Research on Human Research Ethics, 2(2), 57-66. 